\title{
Is Open Government Aspect adopted in Local Development Planning?
}

\author{
Alma'arif ${ }^{1}$, Ella L. Wargadinata ${ }^{2}$ \\ \{email: almaarif@ipdn.ac.id,email: almaarif@ipdn.ac.id\} \\ Faculty of Government Management, IPDN ${ }^{1,2}$
}

\begin{abstract}
This paper aims to describes the Open Government aspect's adoption in Local Government Development Planning. Open Government aspects is derived from [1] namely participation, transparency, and collaboration. Research design is using constructivist approach where using theory as a guidance for problem analyzing. This research is using qualitative method in data collecting technique, namely interview and document study. Data coding is processed with NVIVO version 12 plus besides data reduction and data display as a data analyzing method. Research result shows that Participation in development planning is showed with participation level on development planning at village level gradually decrease because citizen assume that program in planning and real program is not same. Transparency in development planning is showed with all program which from citizen is absorbed by local government at sub-district level. But, in local level, prioritize program which will be real program is discussed closely in local assembly building (close system). Collaboration in development planning is showed with several interest affected is involved in development planning with each interest. There is transparency guarantee in every development planning process, and ICT is the primary requirement for adopting open government's aspects in ideal development planning. This research also recommends additional research linked open government, and the enrichment of participation and transparency concept.
\end{abstract}

Keywords: Collaboration, Local Development Planning, Participation, Transparency.

\section{Introduction}

The development of the public administration paradigm since the early 20th century pioneered by Wilson with the Old Public Administration to New Public Governance gave birth to changes in the patterns of interaction between the public and the government as service providers [2]. Changes in the pattern of interaction are indicated by the increasing demands of the community for access to government. One that develops is the concept of Collaborative Governance [3], [4], the concept of Governing by Network [5], and the concept of Open Government [1], [6], [7]. Open Government as a concept originating from the New Public Governance paradigm has developed and has been known since the President of the United States, Barack Obama, introduced it in his state address. The development of this concept is due to the high demands of the United States society to be involved in making public policy.

At the practical level, Open Government internationally through the Global Open Data Index determines 15 (fifteen) aspects that are assessed for transparency, namely 1) Government 
Budget; 2) National Statistics; 3) Procurement; 4) National Laws; 5) Administrative Boundaries; 6) Draft Legislation; 7) Air Quality; 8) National Maps; 9) Weather Forecast; 10) Company Register; 11) Elections Results; 12) Locations; 13) Water Quality; 14) Government Spending; and 15) Land Ownership ("Data Open Government," 2019).

Table.1, Data Open Government

\begin{tabular}{ccc}
\hline Rank & State & Score \\
\hline 1 & Taiwan & 90 \\
\hline 2 & Australia & 79 \\
\hline 2 & Great Britain & 79 \\
\hline 4 & Prancis & 70 \\
\hline 5 & Finlandia & 69 \\
\hline 17 & Singapura & 60 \\
\hline 51 & Thailand & 34 \\
\hline dst & & \\
\hline 61 & Indonesia & 25 \\
\hline & Source: $[8]$
\end{tabular}

It seems that Indonesia is still included in a non-open state with a score of 25, still below Singapore and Thailand, which are both Southeast Asian countries. The table above also shows that only 25 percent of data from 15 aspects of open government data can be accessed. The Global Open Data Index states that Indonesia is only open to the fields of national statistics, legislation, and government budgets, but is still closed to other aspects [8]. This is due to the role of the Central Bureau of Statistics which annually updates national and regional statistics. In addition, the role of the State Secretariat Ministry has provided a special page for people who want to download laws and regulations. Among the data that are not yet open, aspects of air quality, water quality, election results, development planning and budgeting are very difficult to access [9].

In 2018, Indonesia formed the Open Government Indonesia (OGI), which requires each region to carry out administrative reforms with transparency of government administration data to the public [10]. Reported on its official website, OGI obliges every autonomous region, in this case District / City and Province, to reform the public sector by opening data on governance which will lead to high local government initiatives to innovate in response to high community demands [10]. The quote about OGI above implies that currently every autonomous region is obliged to provide data that is open and accessible to the public, including data that is still considered "sacred" for publication such as financial data and development planning.

Half a decade before the establishment of OGI as a national program, the West Java Provincial Government has issued OG policies for districts / cities to villages within the West Java region through Regional Regulation Number 24 of 2012 concerning One West Java Development Data. Article 8 paragraph (2) and paragraph (3) mandate the existence of a connected data unit starting from the village to the province that can be accessed by stakeholders and the community. Another source states that among the many districts / cities in Indonesia, Bekasi District and Bekasi City are regions that have received special guidance from the Ministry of Communication and Information Technology to open data through the realization of smart city [11]. 
As expressed by Obama in his second winning speech that OG is characterized by participation, collaboration and transparency in the implementation of development [6]. Reporting from a local news site which said that the Bekasi Regency Government was at least the area in West Java Province that received the most public complaints to the West Java Province Information Commission, 37 (thirty seven) times in 2018 [12]. The substance of the report is that it is difficult for the public to obtain information, especially from the Development Office regarding budget planning and use. This of course is very contrary to the mandate of the Law on the Openness of Public Information which allows every citizen to obtain public information from public bodies outside of exempt information.

Meanwhile, on the substance of providing information through the provision of official local government websites in the context of transparency, the Bekasi Regency Government is still experiencing internal problems. The unclear main tasks and functions have resulted in the Public Relations section of the Regional Secretariat and the Information and Communication Office at odds regarding the management of local government sites [13]. This contradicts Obama's transparency concept considering that the management of the Website as an instrument of transparency in the implementation of local government requires professionalism of operators and management organizations [1], [14].

In addition, in the aspect of development planning, Bekasi District still has its own problems, especially in rural development. The existence of the Village Fund, the Special Allocation Fund and the Development Fund results in the development object in the village having the same location. Meanwhile, on the other hand, there are villages or parts of the village that are completely undeveloped. This is because the Musrenbang held in the District is only attended by village elites and very few village people [15]. The result is that there are 20 slum villages whose conditions are still slum, even though the development budget disbursed is quite large, namely around 60.2 billion each year. Finally, there are villages that have a development surplus and on the other hand there are villages that have not been touched by regional development. This is contrary to what Batty et al. Stated that a good database is a factor in making public policy [16].

Table.2 , Proposed Priority Development Activities in Bekasi District

\begin{tabular}{cccccc}
\hline No & Sub-District & $\begin{array}{c}\text { Proposed } \\
\text { Activity }\end{array}$ & No & Sub-District & $\begin{array}{c}\text { Proposed } \\
\text { Activity }\end{array}$ \\
\hline 1 & Babelan & 95 & 13 & Pebayuran & 130 \\
\hline 2 & Taruma Jaya & 87 & 14 & Sukakarya & 80 \\
\hline 3 & Sukawangi & 70 & 15 & Sukatani & 62 \\
\hline 4 & Tambelang & 73 & 16 & Cabangbungin & 76 \\
\hline 5 & Tambun Utara & 83 & 17 & Muara Gembong & 61 \\
\hline 6 & Tambun Selatan & 116 & 18 & Setu & 110 \\
\hline 7 & Cibitung & 72 & 19 & Cikarang Selatan & 65 \\
\hline 8 & Cikarang Barat & 126 & 20 & Cikarang Pusat & 124 \\
\hline 9 & Cikarang Utara & 105 & 21 & Serang Baru & 85 \\
\hline 10 & Karang Bahagia & 18 & 22 & Cibarusah & 65 \\
\hline 11 & Cikarang Timur & 34 & 23 & Bojongmangu & 65 \\
\hline 12 & Kedungwaringin & 76 & & &
\end{tabular}


As seen in the table above, Pebayuran Sub-District has the highest number of priority development proposals, around 130 proposals, while East Cikarang Sub-District has the least proposals, namely around 34 proposals for development activities. Thus, this study focuses on the problem of whether the aspects of Open Government are adopted in development planning in Bekasi District. The purpose of this study is to analyze the aspects of open government in development planning in Bekasi Regency and construct an ideal development plan in relation to the adoption of aspects in open government.

\section{Methodology}

This research was conducted for 2 (two) months from 20 October - 19 December 2019 in Bekasi Regency in 2 (two) Districts, namely Cikarang Timur Sub-district and Pebayuran SubDistrict. This is because the Cikarang Timur Sub-district is the one that proposes the least development programs in regional development planning. Meanwhile, Pebayuran Subdistrict had the most proposals for programs in regional development planning. This study uses a constructivism paradigm. This paradigm is used because of the complexity of views and understanding of the meaning of Open Government, especially related to development planning, so it is required to seek a broader meaning [17], [18]. Determination of informants was carried out using 2 (two) techniques, namely criterion-based selection (CBS) for informants who mastered the research focus with specific criteria (Denzin \& Lincoln, 2018), and snowball sampling for the community. CBS is carried out by identifying actors who have a direct relationship to regional development planning policies in Bekasi Regency so that the research informants are the Head of Bappeda Bekasi Regency, Assistant I for Bekasi Regency Government, Regional Secretary of Bekasi Regency. Public Figures, and the general public are obtained from the Snowball Technique.

This study uses data analysis techniques, namely display data, coding data, and conclusions [19], [20]. In order to simplify the data analysis process at the time of the research, this study was assisted by a qualitative data processing application, namely QSR NVIVO version 12 plus [21]. NVIVO is used to process data in the form of interviews, literature studies, and related documents to produce an overview of the conditions of the research results.

\section{Finding and Discussion}

\subsection{Adoption of Open Government aspects in Regional Development Planning}

Development planning as a continuous process from time to time requires the cooperation of various parties to formulate policy options to be taken. This is as expressed by Bratakusumah that development planning is defined as a continuous process by selecting the most appropriate options by involving policy makers to create public welfare [22]. In practice, in Bekasi District development planning has been carried out in accordance with Law Number 25 of 2004 concerning the National Development Planning System which mandates an integrated long, medium and short term development planning from the center to the regions.

The implementation of this regulation requires regions, including Bekasi District, to prepare and determine a Regional Long-Term Development Plan (RPJPD) every 20-25 years, a Regional Medium-Term Development Plan (RPJMD) every 5 years and a Daearh Government 
Work Plan (RKPD) every year. In addition, the government work programs that are structured are the result of the crystallization of proposals from the village to regional levels. Thus, as stipulated in statutory regulations, at every level of government, the aspirations of the community should be absorbed to accommodate their needs from the hamlet to the national level. This is in line with the OG concept which is defined as the idea that the public has the right to access government documents [23]. This OG idea was initiated by the President of the United States Barack Obama in 2009 which established a government system of transparency, public participation and collaboration [1].

\section{A. Participation}

The terminology of participation is often used in every communication that exists between the government and the community in aspects of development, politics and governance. In simple terms, participation is defined as a community involvement to take part in organizational activities. Khairuddin quoted Hoofsteede as saying that participation is "the taking part of more phases of the process" [24]. Development planning in Bekasi Regency has been carried out in accordance with statutory regulations, namely by means of bottom-up planning which is known as the Development Planning Consultation (Musrenbang). This is done to ensure community participation in determining their respective needs. In addition, premusrenbang activities are carried out by conducting socialization in the form of weekly meetings in the village and invitations in writing to the general public to participate in musrenbang activities.

Regional development planning in Bekasi Regency is carried out hierarchically starting from the hamlet level deliberations to the district level deliberations. This is as stipulated in the Regulation of the Minister of Home Affairs as a technical rule of the SPPN Law in attachment to Letter D.2.5 in implementing musrenbang. In addition, the quotation from the interview above shows that the sub-district level musrenbang is to agree on proposals from the hamlet and village level musrenbang results. In the explanation of Permendagri No. 86 of 2017, it was explained that the Sub-district level Musrenbang is a forum for deliberation between stakeholders in order to discuss and agree on priority programs that have been included by the village then integrated with the design activity plan and then integrated again with the district work plan. This is in line with Clark's statement that public participation is an effort to involve the community in the public policy-making process [25] or a community voluntary activity to influence policy makers in the formulation of public policies [26]. With socialization, it can increase community participation in politics and development planning [27]. If space for participation is not provided, there will be public distrust of the government [28]. This distrust has potential when the community acknowledges that the musrenbang is only a formality because only 1-2 percent of the proposed activities are realized in development. As a result, Bappeda revealed that there is a decrease in the level of community participation in musrenbang every year. Ideally, musrenbang will be an effective medium in realizing the wishes of the people. Therefore, Clark in identifying the definition of participation said that participation can create social justice, but if participation is deemed to have no impact or result, participation will never improve the quality of social justice [25]. This has the potential to become a reality if you see the recognition from the community represented by community leaders in East Cikarang District, they feel that it is futile to participate in the sub-district musrenbang. 


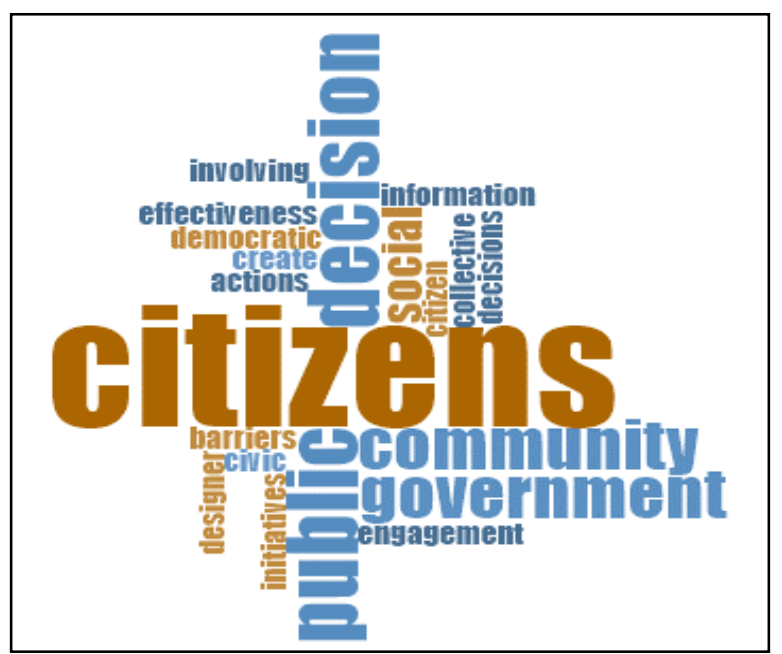

Fig.1, Word Cloud of Participation

Source: Organized by NVIVO 12 plus.

The main aspect that is most often discussed when examining participation is citizens (citizens). Citizens in participation as stated by several sources must be active and involved in making public policies related to the public interest [26], [29], [30]. If this is not done, then what will happen is a gap between citizens and their representatives (in this case the government) who eventually become passive citizens [28].

\section{B. Transparency}

The practice of government administration recognizes the term transparency as a guarantee of people's freedom to obtain information about policies, from formulation to evaluation. Agoes and Ardana define transparency as "... the obligation of organizational managers to prioritize the principle of openness in the decision process and delivery of information" [31]. Law No. 14 of 2008 on Freedom of Information. The law on public information disclosure defines public information as "... information that is generated, stored, managed, sent, and / or received by a Public Agency related to state administrators and / or administrators and other public bodies in accordance with the Law and other information relating to public information". Transparency is also used as a principle in development planning as regulated in Minister of Home Affairs Law No. 86 of 2017 that "... the principle of transparency is to open oneself to the rights of the public to obtain correct, honest, and nondiscriminatory information regarding the implementation of Regional government while still paying attention to the protection of personal, class and state secrets human rights".

The regulation regarding public information disclosure mandates open access to development planning from planning to activity programs. The process can be done either directly or electronically with a certain time [32], [33]. In this regard, to ensure transparency, an official report on the results of the musrenbang is signed, which includes proposals for activities in the sub-district scope. In addition, there are efforts by the sub-district government to always be transparent in the sub-district musrenbang, namely through direct socialization and invitations to the public. 
At the sub-district level musrenbang level, the sub-district is trying to be transparent in accommodating community needs, but when implementing the district level musrenbang and activities to determine activities at the DPRD, there is no guarantee from the government, in this case the Sub-district head and the Bappeda, that the proposed sub-district musrenbang results can be accommodated. The form of transparency is to announce on the government website the results of the district musrenbang in the form of a list of activities that will be carried out without presenting the process of determining program proposals that become real programs. Of course, there is a lack of transparency in one of the district level musrenbang processes. Therefore, de Cruz said that the availability of information displayed on local government websites does not indicate the quality of democracy, but can increase community empowerment to be able to control local government activities [32].

Transparency is also related to the government's efforts to make the community active by giving a role in determining public policies including development planning [32]. If the government's efforts to determine regional development activities are carried out in a semitransparent manner, while transparency mandates the openness of all government activities, it will create a negative relationship between the government and the community, as an example of decreasing community participation in sub-district musrenbang activities. This has been pointed out by Worthy that "... positive relationships between the use of e-government and eparticipation to improve transparency, accountability, and political trust" [34].

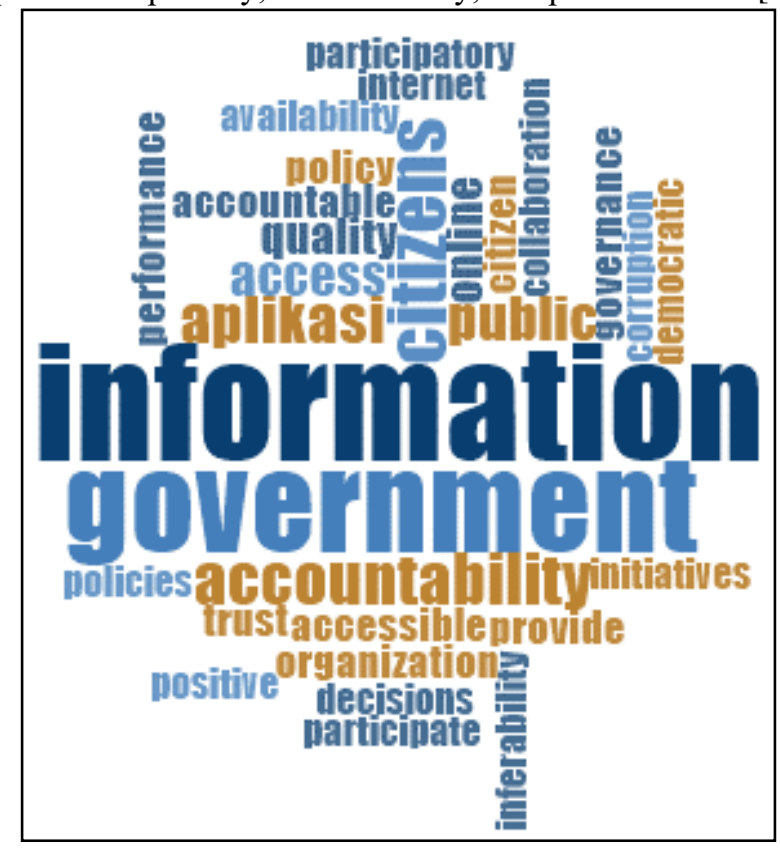

Fig 2. Word Cloud of Transparency

Source: Organized by NVIVO 12 plus.

Information is an important aspect in the transparency of development planning in Bekasi District. This seems to be consistent with the development planning activities in Bekasi District, considering that one of the factors that has resulted in decreased community participation in musrenbang is the closure of information regarding the mechanism for determining activities 
carried out during the meeting with the DPRD. In addition to the availability of information [32], accessible information is also the focus of transparency. This can be seen when local governments publish activities that have been agreed upon on the local government website in the hope that the community will find out about development activities in their area. This is in line with the results of Bearfield's research which states that people are more likely to access data related to finance and planning compared to human resource data [35]. Transparency is also related to the quality of the information produced, if the information produced is still in doubt (less evidence), it can be considered unfair [34], [36].

\section{Collaboration}

Collaboration is a common term in describing a cooperative relationship carried out by more than one party. Many definitions of collaboration are expressed by experts with different points of view. But the diversity of definitions has in common, namely cooperation and division of tasks. Emily R. Lai defines collaboration as mutually beneficial cooperation in coordination to solve common problems. In detail, it was stated that "Collaboration is the mutual engagement of participants in a coordinated effort to solve a problem together. Collaborative interactions are characterized by shared goals, a symmetry of structure, and a high degree of negotiation, interactive, and interdependence " [37]. Regional development planning as regulated in the Regulation of the Minister of Home Affairs Number 86 of 2017 concerning Procedures for Planning, Control and Evaluation of Regional Development, Procedures for Evaluating Draft Regional Regulations concerning Long-Term Regional Development Plans and Regional Medium-term Development Plans, and Procedures for Changing Development Plans Long-term regions, Regional Medium-Term Development Plans, and Regional Government Work Plans mandate the involvement of various stakeholders. The involvement of these stakeholders of interest is also clearly stated in the SPPN Law that “... absorbs the aspirations of the community concerned, including professional associations, universities, NGOs, traditional and religious leaders, as well as the business world. This was done for common interests not personal interests. The mandate of the above regulations shows that regional development planning does not only involve government actors and the community but more broadly to involve the private sector.

The practice of development planning in Bekasi District involves parties who are considered to have good interests from community leaders as expressed by the Head of Cikarang Timur and Pebayuran that "... Village Heads and Village Officials, District Apparatus, Community, Religious Figures, Youth Leaders, Community Figures, Principals and Teachers, Heads of Puskesmas and UPTD in the District ". Meanwhile, the SPPN Law adds to the private sector which states that "... absorbs the aspirations of the community concerned, including professional associations, universities, NGOs, traditional and religious leaders, as well as the business world". This was done for common interests not personal interests. The mandate of the above regulations shows that regional development planning does not only involve government actors and the community but more broadly to involve the private sector. This is not much different from what Scott expressed that: "... broader network of actors and institutions, system context influences the extent to which (or whether) different actors are able to benefit from such arrangements" [38].

As for the interested parties because each character or actor present carries their interests (not personal interests) to be accommodated in proposed development priorities [38]. This is because people who know their needs and leaders at the lowest level are expected to represent the community in voicing their needs into a development program [39]. Collaboration is still needed as long as there are matters that have irritation with other parties who have collaborated. 
It is also important to understand that in order to carry out collaboration, the performance of public institutions is a concern because it will determine whether the collaboration will run smoothly. In the context of time duration, collaboration has a longer time duration compared to cooperation. Therefore, collaboration can also be defined as a continuous collaborative relationship between several parties [40]. Development planning in the context of collaboration can be interpreted as an institutional and structured process to involve sectoral actors, relating hierarchically and geographically in order to solve common problems [38], [41].

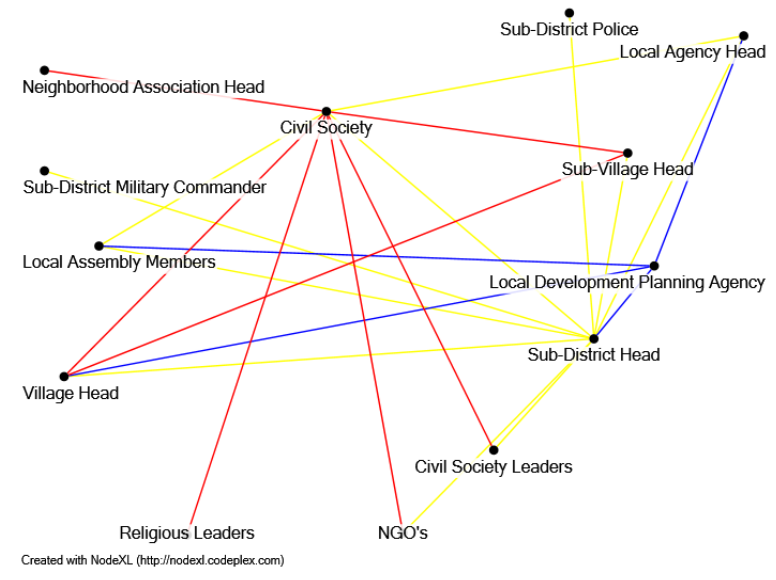

Fig.3, Actors in Collaboration for Development Planning Source: Organized by NodeXL, 2020.

The sub-district level Musrenbang is the most complex musrenbang activity for the actors involved. This can be seen from the actors connected with the yellow line. At the Subdistrict musrenbang, the actor who has a central role is the sub-district head. This is because at the sub-district level musrenbang, the sub-district head coordinates all suggestions for regional development programs from all villages, community leaders, hamlets and others. This is as stipulated in the Regulation of the Minister of Home Affairs as a technical rule of the SPPN Law in attachment to Letter D.2.5 in implementing musrenbang. In addition, the quotation from the interview above shows that the sub-district level musrenbang is to agree on proposals from the hamlet and village level musrenbang results. In the explanation of Permendagri No. 86 of 2017, it was explained that the Sub-district level Musrenbang is a forum for deliberation between stakeholders in order to discuss and agree on priority programs that have been included by the village then integrated with the design activity plan and then integrated again with the district work plan.

Meanwhile, at the village level musrenbang, it appears that the most "busy" communities marked with a red line all come from the community. This is because the community is directly involved in determining development priorities at the RT, hamlet and village levels. Meanwhile at the district level musrenbang, Bappeda has a central role in coordinating the results of the sub-district level musrenbang. Therefore the blue line is centered on the District Bappeda. 


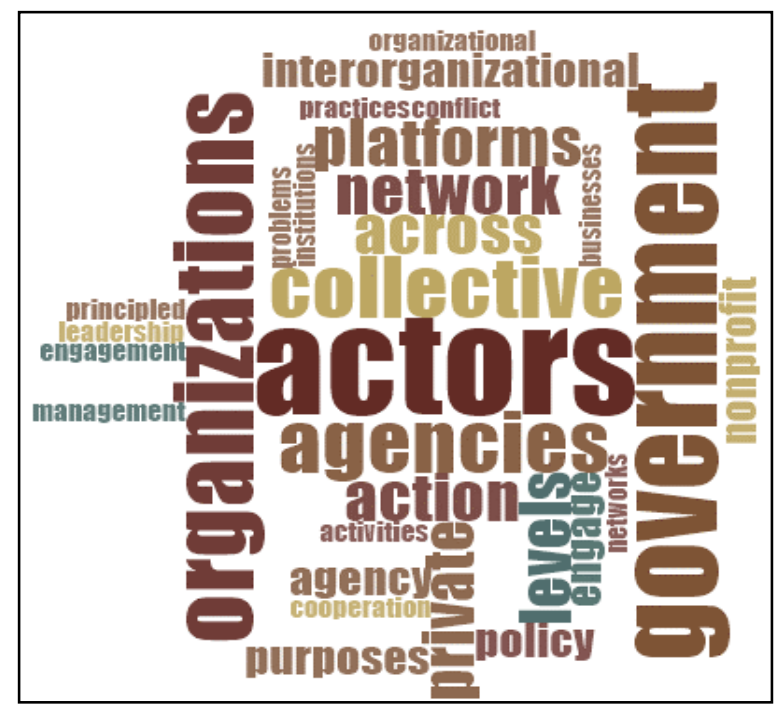

Fig.4, Word Cloud of Collaboration Source: Organized by NVIVO

Collaboration is very closely related to the existence of actors (actors). Actors in collaboration are a network of parties with an interest, especially in development planning, are actors who are interconnected, such as between the community and DPRD members, between the community and the village head, and others. In addition, actors in several previous studies were always related to the involvement of related parties sectorally, such as NGOs and the Social Service, hierarchically, such as the sub-district head and district head and others. Development planning in Bekasi District has adopted OG aspects. However, this aspect has not been running simultaneously in the development planning process in Bekasi Regency. The open government aspect in Bekasi Regency development planning is based on secondary data and primary data can be seen in the following figure:

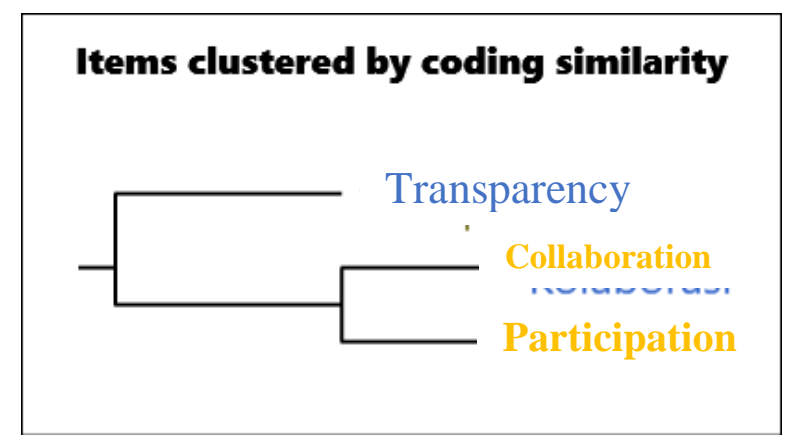

Fig.5, Open Government Issue in Local Development Planning Source: Data organized by authors, 2020

It can be seen in the chart above that the concept of open government in development planning in Bekasi Regency is generally understood as a process of transparency of information in local government administration. The Bekasi District Development Planning Agency 
considers that open government is a process to create open government in the form of transparency of government activities. In addition, the sub-districts both Cikarang Timur and Pebayuran sub-districts basically say that open government is a "... movement with the government and society in realizing transparency to accelerate the optimization of performance and quality of public services". This is in line with what Hansson expressed that "... the rhetoric in the dominant discourse supports the concept of open government formulated by the Obama administration as transparency, participation, and collaboration, but in practice, the focus is predominantly on transparency and information exchange, while ignoring fundamental democratic issues regarding participation and collaboration " [28]. This is evident from seeing the regional development planning process in the Bekasi district starting from the village musrenbang / hamlet meetings to the very participatory, collaborative, and transparent subdistrict development planning meetings. is the degradation of participation and automatically the accountability mechanism cannot be enforced [32].

\subsection{The Ideal Concept of Local Development Planning in order to adopting Open \\ Government Aspects}

The ideal development planning that can adopt aspects or elements of the open government concept is obtained by looking at the real conditions of the obstacles and challenges experienced by the executors of development planning, namely the Sub-district head and the Bappeda circles. In relation to this, the main challenge faced by the Head of the Cikarang Timur Sub-district in implementing the Sub-district musrenbang as admitted is the low level of public awareness in receiving information. In addition to the challenges of the level of public awareness and education, in Pebayuran Sub-District, as recognized by the Sub-district head, the human resources (HR) in Pebayuran Sub-District are still limited, where the majority of employees are contract / non-PNS workers who can leave at any time and stop helping the administration of government in the Office. In addition, the number of villages is a challenge for Pebayuran SubDistrict in its development planning.

The challenge of awareness and education level of the community which is the reason for the ineffectiveness of the musrenbang in the sub-district by the sub-district is resolved by optimizing the role of the village head to provide understanding and get closer to the community to actively participate in development planning. Meanwhile, the condition of the area and the number of villages owned by the Pebayuran Sub-District by the Sub-district head as interviewed is anticipated by conducting monthly and weekly socialization when the musrenbang will be held. The government, in this case the Bekasi District Bappeda, also faces challenges in implementing regional development planning. Understanding of internal stakeholders becomes a separate obstacle in formulating performance indicators. Not only for human resources, the obstacle for Bappeda in development planning as recognized by the Head of Government Division is the budget. The budget is said to have not followed the program (money follows the program) and is still based on routines and political intervention. Political intervention as an external obstacle to Bappeda in realizing participatory development was also acknowledged by the Secretary of Bappeda who said that "... political interests are strong and there are still differences in views with DPRD institutions". Apart from obstacles to political intervention, the effectiveness of regional development planning is acknowledged by Bappeda as well as the changing policies both from the province and from the government which often make adjustments to performance indicators and technical development issues take a lot of time.

In addition to identifying the problems and efforts that have been made, ideal regional development planning that can accommodate the concept of open government can be continued 
by looking at the ideal conditions and expectations expressed by the community and local government of Bekasi Regency. Head of Cikarang Timur sub-district hopes that development planning can be carried out with the integration of APBDes and APBD. In addition to the integration of the APBDes and APBD, the East Cikarang sub-district head emphasized the existence of transparency in the entire musrenbang process up to program implementation. This is because the decreasing community participation in the musrenbang in Bekasi Regency is partly due to the inaccessibility of community proposals or sub-district proposals in the subdistrict musrenbang. Therefore, according to the opinion of the Head of Cikarang Timur Subdistrict, the actors who have a central role in ensuring the transparency of development planning are Bappeda and DPRD.

Monitoring of proposed activities in the pre-district development planning process (musrenbangdes) is a crucial process according to the opinion of the Head of Pebayuran Subdistrict. by the community is really important and very much needed by the community ". This monitoring process in the OG concept is one of the characteristics of the collaboration expressed by Sedgewick that "... are activities and ongoing interactions that provide both structure and meaning to collective action (i.e. planning until monitoring)" [42]. The use of ICT in the current era seems to be a necessity in government administration, including development planning. The use of ICT is currently leveraging the existence of participation and transparency, as stated by Cruz that "... demand for information by citizens and businesses as well as their affirmative steps to make information about government affairs public without waiting for specific requests and, through the use of ICTs" [32].

Development planning in Bekasi District as described in the previous sub-section has indirectly adopted the aspects contained in the OG concept, namely transparency, participation and collaboration. This discontinuity occurs due to the existence of a set of macro laws and regulations that regulate the collaboration, participation and transparency mechanisms. In fact, Ministerial Regulation No. 86/2017 is a technical regulation that regulates very detailed regional development planning and is ideal. However, at the implementation level, these regulations are perfect to apply (too good to be true). This is because politically, this regulation will experience many challenges, even though administratively it is ideal. Adoption of indirect aspects of OG needs to be integrated because these three aspects are one unit that will relate to one another. Collaboration as a collective action will not be created without the participation that follows (Ansell \& Gash, 2008; McDermott, 2010; Ulibarri \& Scott, 2017). Meanwhile, public participation in controlling the government will not emerge when transparency mechanisms are not implemented [32], [34], [36]. Adopting the OG model proposed by Shanab, the OG flow is obtained in the development planning of Bekasi Regency which can be seen in the figure below: 


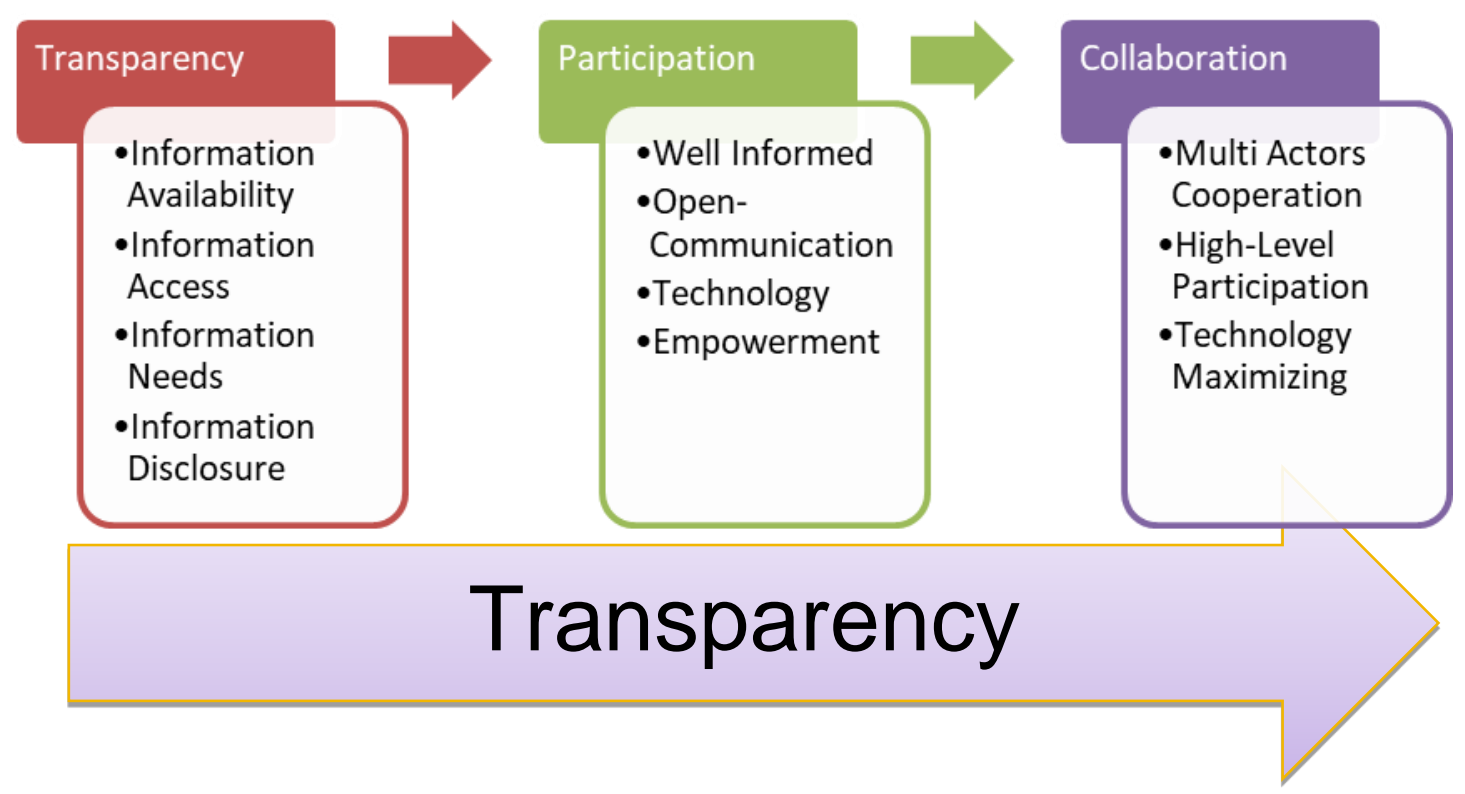

Fig.6, The Flow of Open Government Aspects in Regional Development Planning

Source: Organized by authors, 2020.

The flow of OG in development planning above can be explained that transparency is the first element in OG that leverages community participation. In addition, transparency as a principle forms the basis for the development planning mechanism from the beginning of the village level musrenbang to the district level musrenbang. Development planning transparency is driven by the availability of information (information availability) related to development targets to be carried out in a region. This was stated by the Head of the Cikarang Timur Subdistrict that before the sub-district musrenbang begins, the regional government will announce the development targets and announce the development activities that are temporarily being built in the area. In addition, in regional development planning, local government and the community need a means of communication where the local government is the source of development information and the budget while the community is the object of development. The forum is a musrenbang where the community can get clear information about the needs and follow-up of development carried out (Accessible of Information \& Information Need). Some experts say that public participation will be ineffective if there is no transparency mechanism following the process. As expressed by Bappeda circles, participation is the participation of the community to accommodate their interests in the development planning process. The desire to participate is driven by the existence of a well and clear informed development plan. Good and clear information apart from being informed directly through musrenbang and outreach, is also conveyed through the official website of the district government and the application of the regional management planning system (Using ICT and Consulting). The end is that the community is empowered in determining the development program to be implemented in its area (empowerment and involvement). 
An empowered society will be able to fight for what it needs. Therefore, in the collaboration stage, there will be cooperation between government, private, NGO, DPRD and other interested parties (high level of cooperation). As stated by Scott that "... both by the behavior of individual network actors (eg, to partners with politically powerful actors, align with shared interests, or optimally allocate time and effort spent collaborating) and structural considerations (eg, social capital, network connectivity, and multi-level networks)" [38]. Due to the complexity of the actors involved in regional development planning, automatically the level of participation in the collaboration aspect is very high (high participation). The conventional musrenbang model that must be attended by stakeholders directly in the meeting room will find it difficult to accommodate and gather these actors so that a mobile application is needed that can be used by the actor to monitor the progress of his development proposal (utilizing of application) as expressed by Febrianingsih [9].

\section{Conclusion}

To ensure that development planning always adopts open government aspects, it is necessary to operationalize aspects of transparency (accessibility, accuracy of information, comprehensive information), aspects of collaboration (cooperation and application use), and participation (informing, consulting, and involving) which are then poured out. in the regional technical regulations concerning the regional development planning mechanism in Bekasi District. So that the adoption of OG aspects in development planning has been designed by designed. To ensure transparency in every stage of the musrenbang, it is necessary to use the application and use of local government media, especially local television, which broadcasts the discussion process directly until the development program is determined. The role of the media is very much needed in this aspect.

\section{References}

[1] B. Obama, "OPEN GOVERNMENT: A Progress Report to the American People," 2009.

[2] D. Osborne and T. Gaebler, Reinventing Government: How the entrepreneurial spirit is transforming the public sector. 1992.

[3] C. Ansell and A. Gash, "Collaborative platforms as a governance strategy," J. Public Adm. Res. Theory, vol. 28, no. 1, pp. 16-32, 2018, doi: 10.1093/jopart/mux030.

[4] K. Emerson and T. Nabatchi, "Collaborative governance and collaborative governance regimes," Collab. Gov. Regimes, vol. 086, pp. 1-30, 2015.

[5] S. Goldsmith and W. D. Eggers, Governing by the Network: the New Shape of Public Sector. Washington: Brookings Institution Press, 2004.

[6] L. Lathrop, D \& Ruma, Open goverment: collaboration, transparency, and participation in practice, vol. 53, no. 9. 2013.

[7] P. McDermott, "Building open government," Gov. Inf. Q., vol. 27, no. 4, pp. 401-413, 2010, doi: 10.1016/j.giq.2010.07.002.

[8] “Data Open Government," Global Open Data Index. 2019.

[9] Nunuk Febrianingsih, "Keterbukaan Informasi Publik dalam Pemerintahan Terbuka Menuju Tata Pemerintahan Yang Baik," Rechts Vinding Online, vol. 1, no. 10, pp. 277 
294, 2012.

[10] "Open Government Indonesia," Open Government Indonesia. 2019.

[11] Leski Rizkinaswara, "Gerakan Menuju 100 Smart City,” Kemeterian Komunikasi dan Informatika. 2018.

[12] "Soal Keterbukaan Informasi Publik, Pemkab Bekasi 37 Kali diadukan ke KIP Jabar," Beritacikarang. 2018.

[13] Mahmud, "Diskominfo dan Humas Saling Menyalahkan Terkait Pengelolaan Laman Pemkab Bekasi," Pojok Bekasi. 2019.

[14] G. Lee and Y. H. Kwak, "An Open Government Maturity Model for social media-based public engagement," Gov. Inf. Q., vol. 29, no. 4, pp. 492-503, 2012, doi: 10.1016/j.giq.2012.06.001.

[15] T. Berita, "21 Desa Kumuh, Dana Desa Rp 60,2 M Lebih Terbuang Sia-Sia, Pemerintah Gagal?," Klik Berita. 2018.

[16] M. Batty et al., "Smart cities of the future," Eur. Phys. J. Spec. Top., 2012, doi: 10.1140/epjst/e2012-01703-3.

[17] L. Blaxter, C. Hughes, and M. Tight, HOW TO RESEARCH SECOND EDITION. 2001.

[18] J. A. Maxwell, Qualitative Research Design: An Interactive Approach, 3rd Editio. Los Angeles: SAGE Publication, 2012.

[19] A. Huberman and M. Miles, "Understanding and Validity in Qualitative Research," in The Qualitative Researcher's Companion, 2012.

[20] J. Saldaña, The coding manual for qualitative researchers. New Delhi: SAGE Publication, 2009.

[21] P. Bazeley and L. Richards, The NVIVO Qualitative Project Book. 2011.

[22] Riyadi and D. S. Bratakusumah, Perencanaan Pembangunan Daerah: Strategi Menggali Potensi dalam Mewujudkan Otonomi Daerah. Jakarta: Gramedia Pustaka Utama, 2003.

[23] D. Luthrop and L. Ruma, Open Government. Collaboration, Transparency, and Participation in Practice, I., no. 1. California: O'Reilly Media, 2010.

[24] S. Khairuddin, Pembangunan Masyarakat. Yogyakarta: Liberty, 2000.

[25] J. K. Clark, "Designing Public Participation: Managing Problem Settings and Social Equity," Public Adm. Rev., vol. 78, no. 3, pp. 362-374, 2018, doi: 10.1111/puar.12872.

[26] S. Kim and J. Lee, "E-Participation, transparency, and trust in local government," Public Adm. Rev., vol. 72, no. 6, pp. 819-828, 2012, doi: 10.1111/j.15406210.2012.02593.x.

[27] Y. Djuyandi and A. G. Herdiansah, "Political Participation of Youth in the West Java Regional Election (Pilkada) in 2018," J. Bina Praja, vol. 10, no. 2, pp. 195-207, 2018, doi: 10.21787/jbp.10.2018.195-207.

[28] K. Hansson, K. Belkacem, and L. Ekenberg, "Open Government and Democracy: A Research Review," Soc. Sci. Comput. Rev., vol. 33, no. 5, pp. 540-555, 2015, doi: 10.1177/0894439314560847.

[29] S. Y. Lee, J. M. Díaz-Puente, and S. Martin, "The Contribution of Open Government to Prosperity of Society," Int. J. Public Adm., vol. 42, no. 2, pp. 144-157, 2019, doi: 10.1080/01900692.2017.1405446.

[30] N. Veljković, S. Bogdanović-Dinić, and L. Stoimenov, "Benchmarking open government: An open data perspective," Gov. Inf. Q., vol. 31, no. 2, pp. 278-290, 2014, doi: 10.1016/j.giq.2013.10.011.

[31] S. Agoes, Etika Bisnis dan Profesi. Jakarta: Salemba Raya, 2009.

[32] N. F. da Cruz, A. F. Tavares, R. C. Marques, S. Jorge, and L. de Sousa, "Measuring 
Local Government Transparency," Public Manag. Rev., vol. 18, no. 6, pp. 866-893, 2016, doi: 10.1080/14719037.2015.1051572.

[33] S. S. Dawes, "Stewardship and usefulness: Policy principles for information-based transparency," Gov. Inf. Q., vol. 27, no. 4, pp. 377-383, 2010, doi: 10.1016/j.giq.2010.07.001.

[34] B. Worthy, P. John, and M. Vannoni, "Transparency at the parish pump: A field experiment to measure the effectiveness of Freedom of Information requests in England," J. Public Adm. Res. Theory, vol. 27, no. 3, pp. 485-500, 2017, doi: 10.1093/jopart/muw063.

[35] D. A. Bearfield and Ann O'M. Bowman, "Can You Find It on the Web? An Assessment of Municipal E-Government Transparency,” Am. Rev. Public Adm., vol. 47, no. 2, pp. 172-188, 2016, doi: 10.1177/0275074015627694.

[36] R. Taylor, T. Kelsey, S. Practical, R. Taylor, and T. Kelsey, "Book Review Review of Transparency and the Open Society: Practical Lessons for Effective Policy," pp. 1-2, 2017, doi: 10.1093/jopart/mux010.

[37] E. R. Lai, Collaborations: A Literature Review. London: Pearson Inc, 2011.

[38] N. Ulibarri and T. A. Scott, "Linking network structure to collaborative governance," $J$. Public Adm. Res. Theory, vol. 27, no. 1, pp. 163-181, 2017, doi: 10.1093/jopart/muw041.

[39] W. Y. Essa, "Capturing Social Capital Through Bandung City Community Index Arrangement and Development," J. Bina Praja, vol. 10, no. 2, pp. 169-181, 2018, doi: 10.21787/jbp.10.2018.169-181.

[40] A. B. Whitford, S. Y. Lee, T. Yun, and C. S. Jung, "Collaborative behavior and the performance of government agencies," Int. Public Manag. J., 2010, doi: 10.1080/10967494.2010.529378.

[41] C. Ansell and A. Gash, "Collaborative governance in theory and practice," J. Public Adm. Res. Theory, vol. 18, no. 4, pp. 543-571, 2008, doi: 10.1093/jopart/mum032.

[42] D. Sedgwick, "Building collaboration: Examining the relationship between collaborative processes and activities," J. Public Adm. Res. Theory, vol. 27, no. 2, pp. 236-252, 2017, doi: 10.1093/jopart/muw057. 